\title{
Internet Access in the New Brazilian Normal: A Basic Need for Access to Income, Health, and Education
}

Flávio Fabrício V. M. Ferreira ${ }^{1,2}$, Flávio G. O. Soares Filho ${ }^{1},{ }^{2}$, Wanderson Guimarães de Lana ${ }^{1}{ }^{2}$, Rafael Pimentel dos Santos $^{1,2}$, Philippe Cedraz Lopes ${ }^{1},{ }^{2}$, Marcus V. Topázio Fernandes ${ }^{1,},{ }^{2}$, Renelson Ribeiro Sampaio ${ }^{2}$, Thiago B. Murari ${ }^{1{ }^{2}}$ ${ }^{1}$ Ford Motor Company, Camaçari, BA, Brazil; ${ }^{2}$ Centro Universitário SENAI CIMATEC. Salvador, BA, Brazil

\begin{abstract}
Remote access to information and services has become a latent reality in Brazil since the emergence of the COVID-19 pandemic in 2020. This paper discusses the importance of the community's access to the internet, and as the web's worldwide is an essential tool for remote working and a supporting pillar for essential services remotely offered such as education, banking, and medical care.
\end{abstract}

Keywords: COVID-19. Teleworking. Telemedicine. Remote Education. Banking Platform.

\section{Introduction}

In 2020, the world faces one of the biggest global public health crises due to the impacts of the new coronavirus (COVID-19), which started in December 2019, in the Wuhan region, China [1]. Social isolation has been adopted as one of the main recommendations from the World Health Organization, aiming to mitigate the impacts of the pandemic, and also to guarantee medical care due to the number of ill people. Controlling the contagion curve of the virus until a treatment or an effective vaccine against COVID-19 gets available is a key objective of the global community.

In this context, areas of the economic sector that have a direct impact on society, such as health, education, and financial aid providers, should be the first to benefit from a flexible working model. Major internet facilities and access then turn to be key enablers to keep essential services available to the community.

Received on 15 June 2020; revised 29 August 2020.

Address for correspondence: Dr. Flavio Fabricio de Melo Ventura Ferreira. Avenida Antonio Carlos Magalhães, 556, Spazio Soberano, T08, Apt. 806. Salvador, Bahia, Brazil. Phone: +55 71 999753434. E-mail: flaviofabricio@gmail. com/fferre50@ford.com.

J Bioeng. Tech. Appl. Health 2020;3(3):298-304.

(C) 2020 by SENAI CIMATEC. All rights reserved.
Teleworking, Sustainable Development, and Corporate Development

In the last decades, there was an important growth in both the distance and the time spent on journeys to work. Nowadays around the world, disregarding some metropolis that has a good subway infrastructure, this journey, or part of it, is performed by cars, motorcycles, or buses [2]. In this way, these people's workaday journey is responsible for about $12 \%$ of Carbon Dioxide 2019 emissions globally [3]. The World Greenhouse Gas Emissions detailed the distribution of Carbon Dioxide in 2016 around the world (Figure 1) [4].

With the COVID-19 pandemic, many companies had to incorporate the teleworking or home-office model, aiming to follow with your normal operations working. However, it speeds up a work model flexibilization that had being slowly growing. Thus, in some months is already possible to perform a pre-analysis of many subjects related to teleworking, whether positives or negatives (Figure 2) [2].

Considering all the global engagement with a focus on sustainable development that preserves intergeneration equity, and by contrast, the constant need for companies' productivity improvement, two main teleworking advantages could be highlighted: Employees productivity growth due to daily time gain and worktime flexibilization, resulting in better life quality. Polluting Gase's decrease due to the lower road transport demand on work trips. 
Figure 1. World Greenhouse Gas Emissions in 2016.

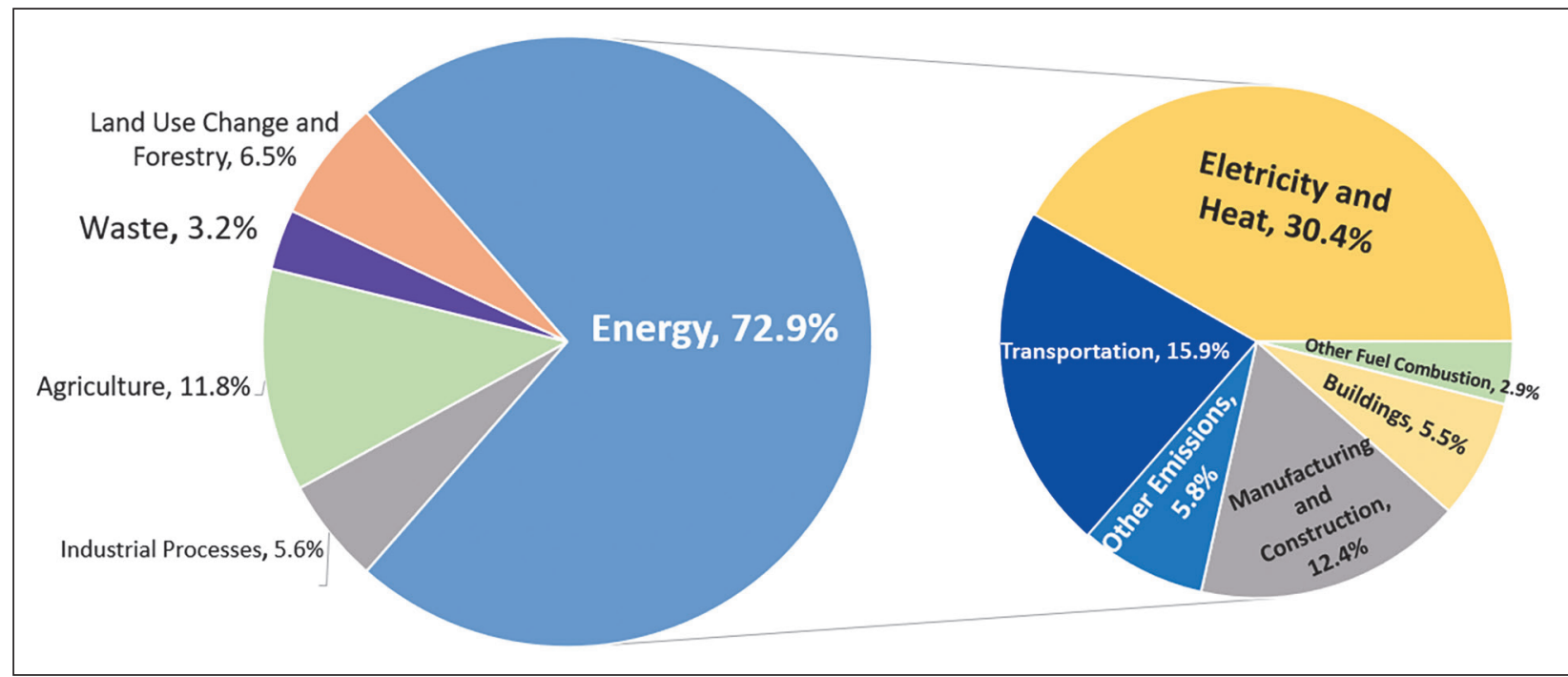

Figure 2. Home-Office advantages and disadvantages.

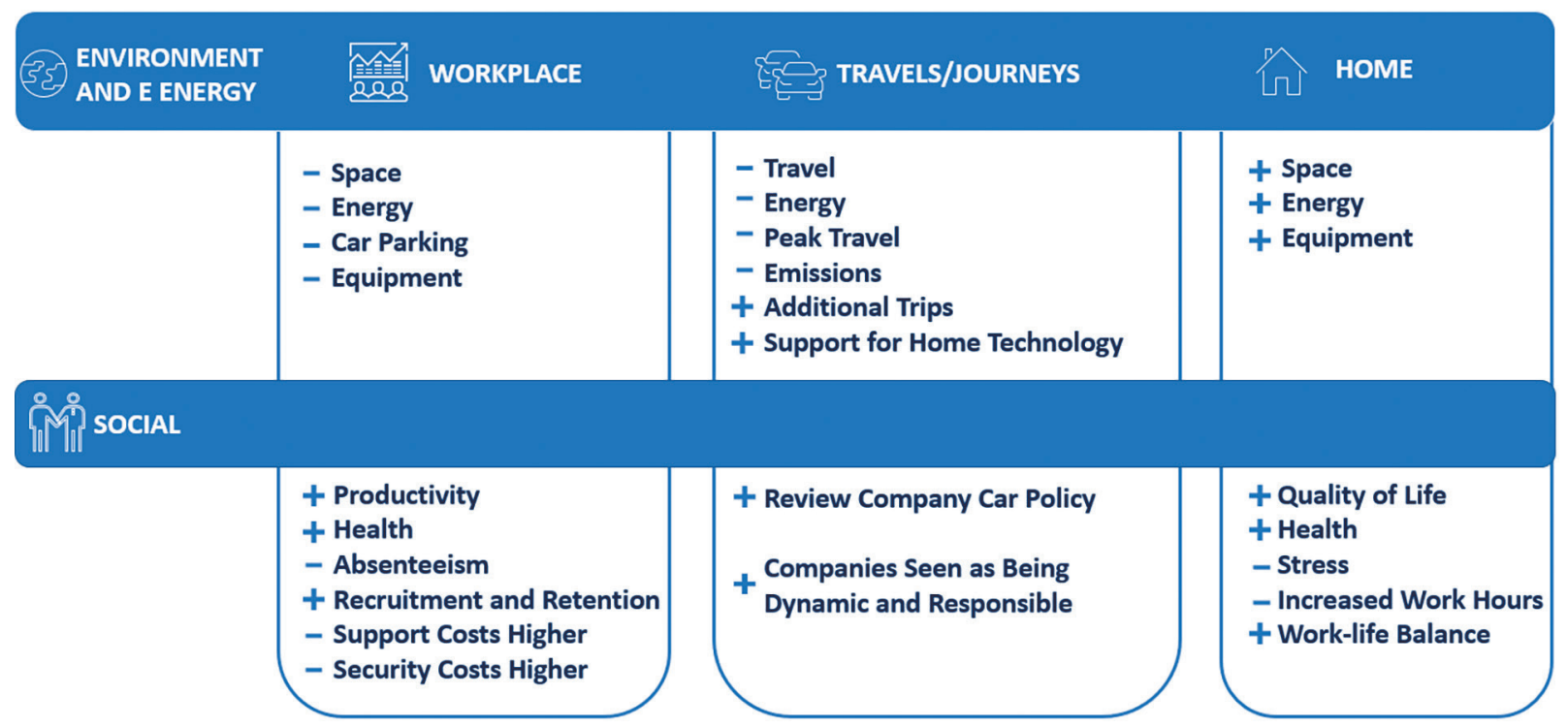

\section{Access to COVID-19 Emergency Financial Aid:} The Social Invisibles Citizens

The social isolation policy during the 2020 COVID-19 pandemic period may be more restrictive depending on the economic and public health situation in each country, but, in general, it directly affects the industrial and commercial activities considered as non-essential. In other words, those activities that are not linked to the guarantee of health, food, and supply of the necessary goods to maintain the productive chain available for public services and essential activities were not allowed to keep working.

The halt of several economic sectors due to Brazilian social isolation decrees had serious impacts reducing the already deteriorated family's incomes [5]. Mostly affected families are exactly the ones that do not enjoy the privileged of public sector job stability or do not have earnings 
beyond the necessary to cover their basic needs. These families in general have a higher social vulnerability in which people are linked to informal variable income jobs and, consequently, are excluded from constitutional guarantees such as a Time Service Guarantee Fund (FGTS), Social Integration Program (PIS), and unemployment insurance. Furthermore, they do not have the support of unions either homologation of formal maintenance job agreements considering salary reductions. Aiming at this public of lower-income, an emergency aid of R \$ 600 was created by Federal Government, initially in force for a period of 3 months.

The absence of a single national registry repository that makes it possible to identify all people able to receive the government's financial aid generated the need for a new registry for those who claim access to assistance. Since the decision that emergency aid would be paid, many efforts have been made to keep people at home to maintain social isolation. In this sense, the applicant's registration for assistance started to be made preferably via Caixa Econômica Federal cellphone application or webpage which requires plaintiffs' access to the internet. Some state institutions and banks' inefficiencies were revealed to the public during this period. The relevant state's challenge in analyzing social and monetary needs from the population would require an intelligent, robust and centralized government data system, robust enough to avoid delays on resource releases for those who need it most, and also avoid system's frauds.

According to data released in the National Household Sample Survey [6] containing data collected in a survey conducted between 2017 and 2018, about $21 \%$ of Brazilians do not have access to the internet at home. The main reasons for not using the internet at home pointed out by the research were: lack of interest in accessing the internet $(34.7 \%)$, internet access service was too expensive $(25.4 \%)$ and no resident knew how to use the internet (24.3\%). Also, internet access in Brazil is unequal and has different access levels depending on several factors such as housing area (urban or rural), the region of the country, age group, and per capita income. A certain pattern was identified as common in the survey: the household average real income per capita where there was internet frequent usage $(\mathrm{R} \$ 1,769)$ was almost double compared to the income of those who did not use this network ( $\mathrm{R} \$ 940)$. The great difference between these two income groups was observed in all the Major Regions [6]. It is evidenced through the research that those who most need emergency assistance are the people who have restricted access to the internet

\section{Telemedicine}

Telemedicine started to be used in Brazil in the earlier $90 \mathrm{~s}$, in health teaching and research establishments, having its prelude with the Disque Saúde in São Paulo, established as a pioneer information service in 1989, becoming an appointment consultation service in 1991, and expanded to other regions such as Contagem (Minas Gerais), Vitória (Espirito Santo), Curitiba (Paraná), among others [7]. Disque Saúde was an enabler for subsequent programs like Rede Universitária de Telemedicina (RUTE) and the program Telessaúde Brasil, with specific activities in the SUS network, paving the way for future regulations on teleconsultation.

Even considering its long existence, there is still a great dependence on the success of the grouping of existing technologies, to build and allow their integration, supporting complete solutions for the application of telemedicine. Investments in infrastructure, information standards, and systems applied to the area will assure interoperability, services, and a management model, not only limited to financial resources, but also for their development and constitution. Generating as consequence barriers that allow doctors to use their techniques efficiently on remote patient care, accentuated by the moment of the COVID19 pandemic, such as licensing providers for performance and payment; medical malpractice insurance for telemedicine; adherence 
to confidentiality and security regulations; establishment of protocols to manage laboratory tests, prescriptions and programming.

The adoption of telemedicine, within this context and as one of the arms of telehealth actions, according to Caetano [7], can bring benefits, such as the reduction of time of attendance, the costs of transportation for patients and health professionals, improving quality assistance, in addition to allowing specialists to access remote areas, previously not covered by ordinary and face-to-face routes.

To improve the digital health area in Brazil, the government created the Department of Digital Health in 2019, linked to the Ministry of Health, which has implemented National Digital Health Policy and Telehealth in SUS. It covers the entire spectrum of formulation, planning, coordination, monitoring, and evaluation of this implementation, in addition to the development of processes for the elaboration, negotiation, implementation of standards and instruments necessary for the practice of digital health in SUS. It also promotes the expansion of the information network, communication, and integration at the national level, in addition to stimulating and encouraging the exchange of knowledge and experiences between public and private entities, the scientific-technical community, and international organizations working in the field of telehealth, telemedicine and digital health [8].

It is worth mentioning that the successful implementation of telemedicine in the country within SUS, the government, through the Department of Digital Health, should rely on formal and informal links between companies, research institutes, universities, and the government itself, using the networking already established to leverage effective implementation in SUS and country coverage, while promoting the grouping of enabling technologies, human capital formation, and research to improve existing services, in addition to a structured approach to the challenges for successful dissemination of these in the national territory.

\section{Remote Education}

According to Castaman [9], remote education, known as RE, is experiencing an acceleration process due to the context of the COVID19 pandemic. Countries such as Brazil, China, and the United States are developing significant changes associated with remote learning, despite being at different levels of adherence to this methodology. History, features, and opportunities related to RE will be addressed in the next paragraphs. Zhou [10] states that in China, remote learning initiatives started in 1978 and showed great acceleration since 2012, with $70.2 \%$ of Chinese schools with full multimedia capability. Strengthening its policies in the pandemic period, the country launched an online national education program known as "School's Out, but Class's On". The great challenges in its implementation were an adaptation to the remote teaching method and the lack of student's self-autonomy at home. It is a country with 270 million students in basic and secondary education, and 20 million university students, increasing the complexity of initiatives. In Brazil, according to Castaman [9], the strategy related to remote learning started in 1996 through the Law of Guidelines and Bases, being accelerated only in 2015 by the National Education Plan. Provisional Measure 934, from 2020, interrupted face-to-face classes, recommending substitution by remote learning during the pandemic period. Through a survey of 3,300 respondents, the National Emergency Committee Department found that approximately $50 \%$ of students face learning difficulties in remote activities. Alternatives to the maintenance of learning in the country become essential in face of such scenario. Bailey [11] states that strategically addressing distance learning has positive results. In the work, the author elaborated on experiences of remote learning equivalent or superior to face-to-face experiences, associated with improved access to content and a reduction in operating costs. In a survey of six North American universities, promising distance learning practices, such as the 
adaptation of the teaching portfolio, investments in infrastructure, and training. In the pandemic period and also in the post-COVID period19, EAD appears as a vital and efficient element in the learning process.

\section{Materials and Methods}

The research method applied to this article has an observational purpose, aiming the exploration of modern content based on the social and economic sciences. It is analyzed four important aspects related to the changes in human relationships and the international macroeconomic scenario after the COVID-19 pandemic.

Furthermore, in terms of the nature of the research, it is classified as applied and its approach is qualitative, as it allows an analysis of specific characteristics within a given circumstantial context [12]. Moreover, this research has an exploratory character, since it aims to clarify, analyze, and update concepts within a given context and explore an overview of current facts, through a wide investigation [12]. Concerning technical procedures, the methodology of this article uses bibliographic and documentary research [13]. In this context, scientific publications, articles, and documents from private organizations were used as a basis to allow the observational and logical analysis of this presented article.

\section{Results and Discussion}

We are experiencing an unprecedented global crisis due to the pandemic of COVID-19, causing dramatic changes to the world in early 2020, thereby changing the digital behavior of society around the globe. Right now, billions of people turn to connected devices to deal with life and interact in interpersonal relationships, in addition to working safely, where the focus remains on delivering results, but in an increasingly remote way. The internet then goes from a desirable item to an enabling item to a variety of services feasibility.
According to a recent survey conducted by Hootsuite [14] (Figure 3), there was a significant increase in digital and online activities in 2020. In this new context in Brazil, it will be extremely important to provide access to education, health, and communication for the entire community through the essential base element that is the Internet. Governments around the world have made interventions in the pandemic period to keep the crisis as stable and less impactful as possible in different sectors of the economy, from reducing taxes, granting emergency aid in the form of money, improving the health system, and even suspending temporarily loans and debts of citizens and companies.

In the same way that governments aim to promote the economy and the well-being of the country as a whole, it will be necessary to analyze the new basic element that is the internet and guarantee access for the whole society, especially in the most precarious regions, where access to the internet is still limiting, either due to the infrastructure of cities or the cost of providers.

In this perspective, the Brazilian government will be able to study the implementation of new economic and social projects aiming to assure this new basic element, as well as the current rural electrification program "Luz Para Todos", which aims to allow access to electricity for more needy regions. The relevance of internet access in the Brazilian scenario is directly linked to several economic and social sectors, such as education, health, employability, or private companies.

The project feasibility must be associated with several actions linked to the expansion of the internet in the national territory, such as a free supply of the internet to society in most needy communities, direct intervention in the reduction of taxes of the current private internet providers allowing the acquisition of basic electronic and electrical components for the installation of new internet distribution centers, the launch of public notices aimed at the development of new national technologies, improvement in the infrastructures of cities that allow the provision of free 
Figure 3. Internet connections chart.

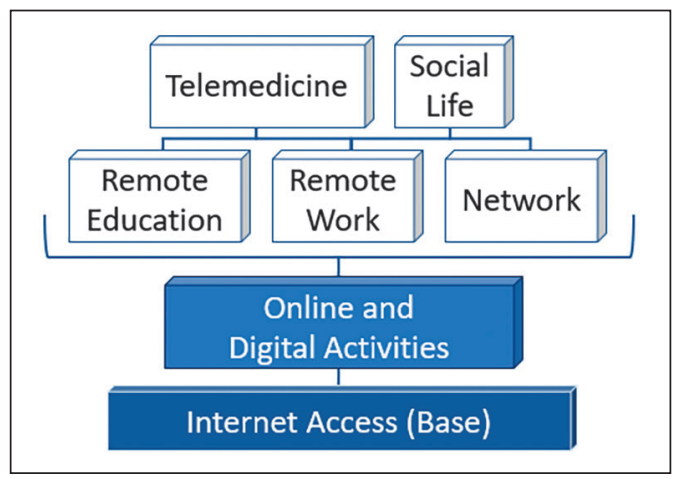

Figure 4. Activities impacted by COVID-19 pandemic in April.

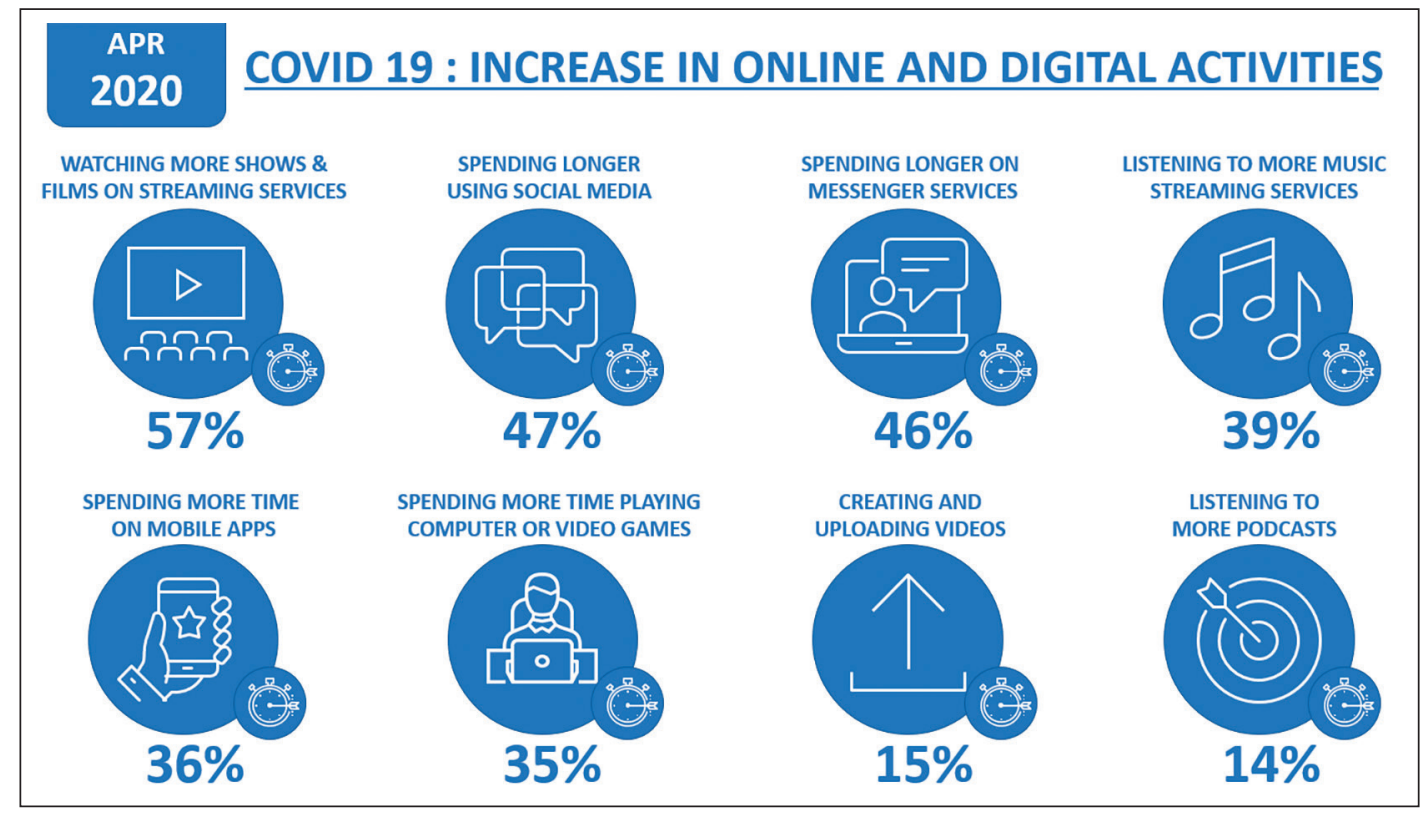

internet in urban centers, also, to accelerate the implementation of the $5 \mathrm{G}$ network in the national territory.

\section{Conclusion}

In an increasingly connected world, where access to government resources for the most basic needs during a pandemic period relies on internet availability, it can be considered that those who are not connected to the network are socially invisible and are excluded from their rights. Despite the recent growth in the use of connected devices, this reality has not yet reached a large portion of the low-income Brazilian population. The recent economic crisis of 2014-2017 also played a major role in the negative impact of household access to the internet and delayed the digital revolution in Brazil, on average the demand for internet access decreased by 8 percentage points due to the situation of economic degradation. This decrease in demand has impacted families from different social classes who, in more adverse conditions, seek cheaper access solutions opting for the use of the internet only in places where this service is public and free. The digital revolution and investments in information and communication technology (ICT) demand a connected society, however, there is no connectivity without access to the internet and 
there is no society without people. Investment in information and communication technologies (ICT) is directly associated with economic benefits, such as increased productivity, lower costs, new business opportunities, job creation, innovation, and increased trade (World Bank, 2018). The growth of ICTs also helps to create incentives to increase the participation of individuals and develop skills to deal with innovations in the digital world.

\section{References}

1. World Health Organization (2020): Coronavirus disease (COVID-19) Situation report -139. Available at: <https://www.who.int/docs/default-source/ coronaviruse/situation-reports/20200607-covid-19sitrep-139.pdf?sfvrsn=79dc6d08_2>. Access by 19 Aug, 2020.

2. Banister, David, Carey Newson, and Matthew Ledbury. "The Costs of Transport on the Environment-the role of teleworking in reducing carbon emissions." Transport Studies Unit, Oxford University. Available at: <http:// www. tsu. ox. ac. uk/pubs/1024-banister-etal. pdf (2007)>. Access by 19 Aug, 2020.

3. Olivier, Jos GJ, and J. A. H. W. Peters. "Trends in global CO2 and total greenhouse gas emissions." PBL Netherlands Environmental Assessment Agency 5 (2019). Available at: <https://www.pbl.nl/sites/default/ files/downloads/pbl-2020-trends-in-global-co2-andtotal-greenhouse-gas-emissions-2019-report_4068. pdf $>$. Access by 19 Aug, 2020.

4. World Greenhouse Gas Emissions in 2016. World Resources Institute. Retrieved on 15 July 2019. Available at: <https://www.wri.org/resources/data-visualizations/ world-greenhouse-gas-emissions-2016>. Access by 19 Aug, 2020.

5. Amitrano C. Medidas de Enfrentamento dos Efeitos Econômicos da Pandemia COVID-19: Panorama Internacional e Análise dos Casos dos Estados Unidos, do Reino Unido e da Espanha, IPEA: 2020. Available at: <http://repositorio.ipea.gov.br/handle/11058/9978>. Access by 19 Aug, 2020.
6. Instituto Brasileiro de Geografia e Estatistica-IBGE (2020): Acesso à internet e à televisão e posse de telefone móvel celular para uso pessoal 2018, PNAD. Available at: < https://biblioteca.ibge.gov.br/index.php/ biblioteca-catalogo? view $=$ detalhes $\& \mathrm{id}=2101543>$. Access by 19 Aug, 2020.

7. Caetano R et al. Desafios e oportunidades para telessaúde em tempos da pandemia pela COVID-19: uma reflexão sobre os espaços e iniciativas no contexto brasileiro. Cadernos de Saúde Pública, v. 36, p. e00088920, 2020. Available at: <https://www.scielosp.org/article/ csp/2020.v36n5/e00088920/>. Access by 19 Aug, 2020.

8. Brasil. Decreto $\mathrm{n}^{\circ}$ 9.795, de 17 de maio de 2019. 2019. Available at: <http://www.planalto.gov.br/ccivil_03/ ato2019-2022/2019/decreto/D9795.htm>. Access by 19 Aug, 2020.

9. Castman AS, Rodrigues RA. Distance Education in the COVID crisis-19: an experience report. Research, Society and Development, v. 9, n. 6, p. 180963699, 2020. Available at: <https://rsdjournal.org/index.php/ rsd/article/view/3699>. Access by 19 Aug, 2020.

10. Zhou L et al. 'School's Out, But Class' On', The Largest Online Education in the World Today: Taking China's Practical Exploration During The COVID-19 Epidemic Prevention and Control As an Example. But Class' On', (March 15, 2020), 2020. Available at: <https://papers. ssrn.com/sol3/papers.cfm?abstract_id=3555520>. Access by 19 Aug, 2020.

11. Bailey A. Making digital learning work, success strategies from six leading universities and community colleges. Boston Consulting Group, 2018. Available at: <https:// www.voced.edu.au/content/ngv:80989>. Access by 19 Aug, 2020.

12. Gil AC. Métodos e técnicas de pesquisa social, Atlas, 6a edição, 2008. Available at: $<$ https://biblioteca.isced. ac.mz/handle/123456789/707>. Access by 19 Aug, 2020.

13. Severino AJ. Metodologia do Trabalho Científico, São Paulo: 2007. Available at: <https://www.sorocaba. unesp.br/Home/Graduacao/EspacodoAluno/diretrizes tg_eca-04.08.15---atualizada.pdf\#page=27>. Access by 19 Aug, 2020.

14. COVID-19 HUB. Digital Around The World In April 2020. Available at: <https://covid19.tabipacademy. com/2020/04/28/digital-around-the-world-inapril-2020/>. Access by 19 Aug, 2020. 